\title{
ESTIMATE OF THE WEIGHT OF JAPANESE QUAIL EGGS THROUGH FUZZY SETS THEORY
}

\author{
Estimativa do peso dos ovos de codornas japonesas por meio da teoria dos conjuntos fuzzy
}

\author{
Jaqueline de Oliveira Castro ${ }^{1}$, Alessandro Vieira Veloso $0^{2}$, Tadayuki Yanagi Junior ${ }^{2}$, \\ Edison José Fassani ${ }^{3}$, Leonardo Schiassi ${ }^{2}$, Alessandro Torres Campos ${ }^{2}$
}

\begin{abstract}
Quail breeding is a viable alternative for animal production and due to its low investment, fast return of invested capital, use of small areas and creation of jobs has aroused much interest in Brazil. The aim of this study was to develop a model based on fuzzy set theory to predict the weight of eggs from Japanese quails. The proposed fuzzy model was based on data from field measurement experiments, as well as from literature referring to the influence of environment over the weight of eggs. To develop the fuzzy system, air dry-bulb temperature $\left(\mathrm{t}_{\mathrm{db}},{ }^{\circ} \mathrm{C}\right)$ and relative air humidity $(\mathrm{RH}, \%)$ were defined as input variables and trapezoidal and triangular membership functions were used, respectively. The absolute deviation between the values for observed egg weight and egg weight estimated by the fuzzy system, varied between $0.01 \mathrm{~g}$ and $0.32 \mathrm{~g}$, and the average deviation was $0.14 \mathrm{~g}$. The average error found was $2.33 \%$, and the determination coefficient $\left(\mathrm{R}^{2}\right)$ was equal to 0.668 . The fuzzy system developed to estimate the weight of Japanese quail eggs, based on the $t_{\mathrm{db}}$ and $\mathrm{RH}$ provided low values for absolute deviation and percentage error, allows a realistic estimate of the weight of eggs in different environmental conditions.
\end{abstract}

Index terms: Quail breeding, fuzzy system, eggs weight.

\section{RESUMO}

A cotornicultura é uma alternativa na produção animal que, pelo baixo investimento, rápido retorno do capital investido, utilização de pequenas áreas e à gereção de novos empregos, tem despertado grande interesse no Brasil. Neste trabalho, objetivou-se desenvolver um modelo baseado na teoria dos conjuntos fuzzy para a predição do peso de ovos de codornas japonesas. O modelo fuzzy proposto foi elaborado com base em dados experimentais oriundos de medições em campo, bem como da literatura, a respeito da influência do ambiente sobre o peso de ovos de codornas japonesas de postura. Para o desenvolvimento do sistema fuzzy, foram definidas, como variáveis de entrada, a temperatura de bulo seco $\left(\mathrm{t}_{\mathrm{bs}},{ }^{\circ} \mathrm{C}\right)$ e a umidade relativa (UR, \%) do ar, sendo utilizadas curvas de pertinência trapezoidais e triangulares, respectivamente. O desvio absoluto entre os valores de peso dos ovos observados e os estimados pelo sistema fuzzy variou entre $0,01 \mathrm{~g} \mathrm{e} 0,32 \mathrm{~g}$, sendo o desvio médio de $0,14 \mathrm{~g}$. O erro médio encontrado foi de $2,33 \%$, e o coeficiente de determinação $\left(\mathrm{R}^{2}\right)$ foi igual a 0,668 . O sistema fuzzy desenvolvido para estimar o peso dos ovos de codornas japonesas, com base na T e UR, proporcionou baixos valores de desvio absoluto e erro percentual, possibilitando estimar de forma realística o peso dos ovos em diferentes condições ambientais.

Termos para indexação: Coturnicultura, sistema fuzzy, peso de ovos.

\section{(Received in october 5, 2011 and approved in february 29, 2012)}

\section{INTRODUCTION}

Quail breeding is an expanding industry, responsible for generating jobs and income at all levels of the production chain (MOURA et al., 2010a). Quail rearing proves interesting because of the small physical space required, in addition to several inherent characteristics of the animal, such as low feed intake, short breeding interval, early sexual maturity and persistence in high egg production. In addition, the high quality of final product and the easy breeding and management of these birds should be highlighted (BARRETO et al., 2007), as the egg is the main product for commercial exploitation (MOURA et al., 2010b).
Quail breeding in Brazil has received investment for upgrading facilities, for the genetic improvement of strains and for diet formulations (MOURA et al., 2008); however, the direct and indirect effects of environment over production and animal welfare (ROCHA et al., 2010) should also be considered. In tropical and subtropical climates, temperature and humidity factors restrict the development, production and reproduction of animals (JÁCOME et al., 2007). For laying quails, the thermo-neutral zone varies from 18 to $22^{\circ} \mathrm{C}$ and between 65 and $70 \%$ relative humidity (LIMA et al., 2011).

Analysis of production parameters and egg quality are examples of some measures adopted to determine the

\footnotetext{
Universidade Federal de Lavras/UFLA - Cx. P. 3037 - 37200-000 - Lavras - MG - Brasil - jaqueline.oliveiracastro@yahoo.com.br

2Universidade Federal de Lavras/UFLA - Departamento de Engenharia/DEG - Lavras - MG - Brasil

3Universidade Federal de Lavras/UFLA - Departamento de Zootecnia/DZO - Lavras - MG - Brasil
} 
effects of rearing environment over the performance and welfare of the birds (ALVES et al., 2007).

In order to better evaluate the environment for animal production, researchers has have looked to innovative evaluation methods, tools for non-invasive assessment and welfare control methods (BORGES et al., 2010). The animal welfare estimative, considering all possible critical associations of the thermal environment, is a problem where the application of fuzzy set theory may appear promising (PONCIANO et al., 2011). The mathematical methods used so far have not proved sufficient to the task of adequately describing the interaction of variables involved in animal environment studies, due to the vast amounts of existing information on appropriate conditions for animal welfare. In this sense, the application of the knowledge from fuzzy set theory proves to be an innovative approach because it is a mathematical theory applied to diffuse concepts. It is an interesting methodology for decision making, enabling control over the thermal environment inside sheds for livestock rearing (AMENDOLA et al., 2004).

Given the above, the objective of this study was to develop a model based on the fuzzy set theory to predict the weight of Japanese quail eggs.

\section{MATERIAL AND METHODS}

A fuzzy model consists of input and output variables. For each variable, fuzzy sets that characterize them are assigned, and, for each fuzzy set a membership function is created.

The proposed fuzzy model was based on experimental data from measurements in an experimental facility from February $10^{\text {th }}$ to May $8^{\text {th }} 2010$, and from April $22^{\text {nd }}$ to June $20^{\text {th }} 2011$, as well as from literature regarding the influence of environment over eggs weights from laying Japanese quail.

To develop the fuzzy model the input variables were defined as air dry-bulb temperature $\left(\mathrm{t}_{\mathrm{db}},{ }^{\circ} \mathrm{C}\right)$ and relative air humidity $(\mathrm{RH}, \%)$. The $\mathrm{t}_{\mathrm{db}}$ is considered the most influential climatic factor over the physical environment of the animal (McDOWELL, 1974) and the RH is another variable that markedly influences the heat balance in environments where heat loss by evaporation is crucial to homeothermy (YOUNG 1988).

Based on the input variables, the fuzzy model predicts the weight of Japanese quail eggs by classifying the environment. The range for the input variables $\left(t_{d b}\right.$, $\mathrm{RH})$, listed in Table 1, is represented by trapezoidal membership functions (Figure 1), as they better represent the behavior of the input data.
Table 1 - Fuzzy sets for the input variables air dry-bulb temperature $\left(\mathrm{t}_{\mathrm{db}}\right)$ and relative humidity $(\mathrm{RH})$.

\begin{tabular}{cc}
\hline & Fuzzy sets \\
\hline & $\mathrm{t}_{\mathrm{db}} 1[15.00 ; 17.59]$ \\
Air dry-bulb temperature & $\mathrm{t}_{\mathrm{db}} 2[16.43 ; 19.90]$ \\
$\left(\mathrm{t}_{\mathrm{db}},{ }^{\circ} \mathrm{C}\right)$ & $\mathrm{t}_{\mathrm{db}} 3[18.70 ; 22.48]$ \\
& $\mathrm{t}_{\mathrm{db}} 4[21.40 ; 25.56]$ \\
& $\mathrm{t}_{\mathrm{db}} 5[24.40 ; 29.10]$ \\
& $\mathrm{t}_{\mathrm{db}} 6[27.20 ; 37.00]$ \\
\hline Relative humidity & $\mathrm{RH} 1[50.00 ; 63.00]$ \\
$(\mathrm{RH}, \%)$ & $\mathrm{RH} 2[57.10 ; 72.49]$ \\
& $\mathrm{RH} 3[67.70 ; 82.54]$ \\
& $\mathrm{RH} 4[78.31 ; 90.00]$ \\
\hline
\end{tabular}
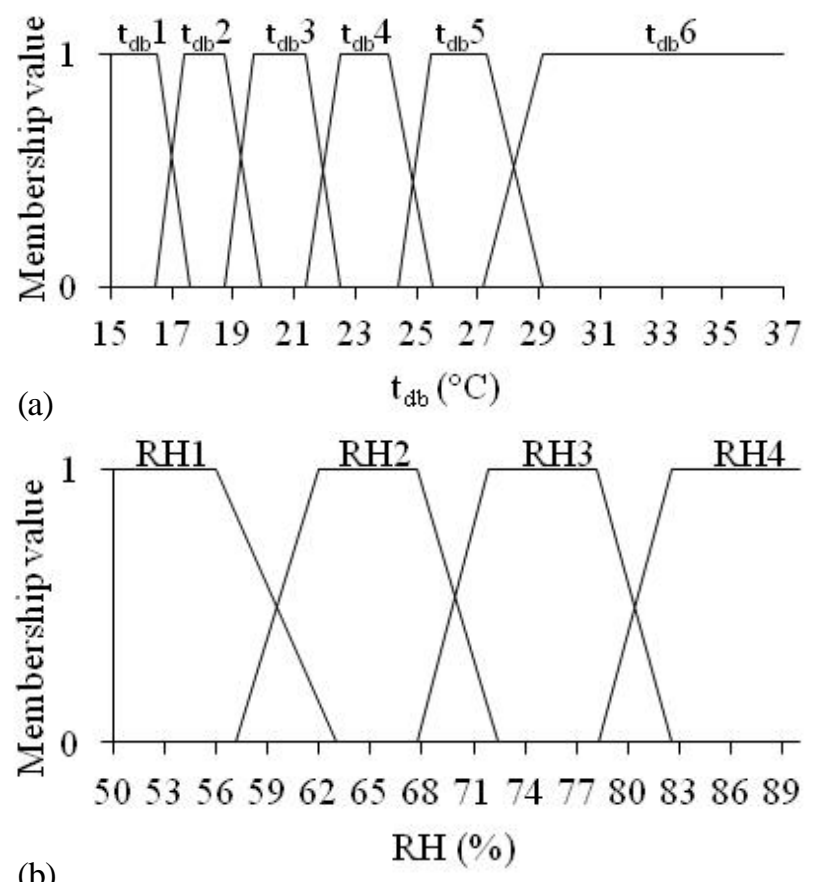

Figure 1 - Membership functions to the input variables, (a) air dry-bulb temperature $\left(\mathrm{t}_{\mathrm{db}}\right),(\mathrm{b})$ relative humidity $(\mathrm{RH})$.

The chosen fuzzy inference method was Mamdani (AMENDOLA; SOUZA, 2004) that, in response, provides a fuzzy set originating from the combination of input values with their respective relevance degrees according to minimum operator, and then by the superposition of the rules through the maximum operator. The defuzzification was carried out using the Gravity Center method (Centroid or Area Center), which considers all 
possible outputs, transforming the fuzzy set, originated by inference, in numeric value, applied to several models reported in the literature (PANDORFI et al., 2007; SCHIASSI et al., 2008; PERISSINOTTO et al., 2009, NASCIMENTO et al., 2011).

The membership functions for the output variables were constructed based on the range adopted for the egg weight output variable (Table 2), in order to do so, triangular membership functions were adopted, as they better represent the data set and result in the lower standard deviation values (Figure 2).

Table 2 - Range of fuzzy sets for the variable eggs weight (EW, g).

\begin{tabular}{cl}
\hline Output variable & \multicolumn{1}{c}{ Fuzzy set } \\
\hline & EW1 $[8.84 ; 10.16]$ \\
Egg weight $(\mathrm{EW}, \mathrm{g})$ & EW2 $[9.50 ; 10.82]$ \\
& EW3 $[10.16 ; 11.48]$ \\
& EW4 $[10.82 ; 12.14]$ \\
& EW5 $[11.48 ; 12.80]$ \\
& EW6 $[12.14 ; 13.46]$ \\
\hline
\end{tabular}

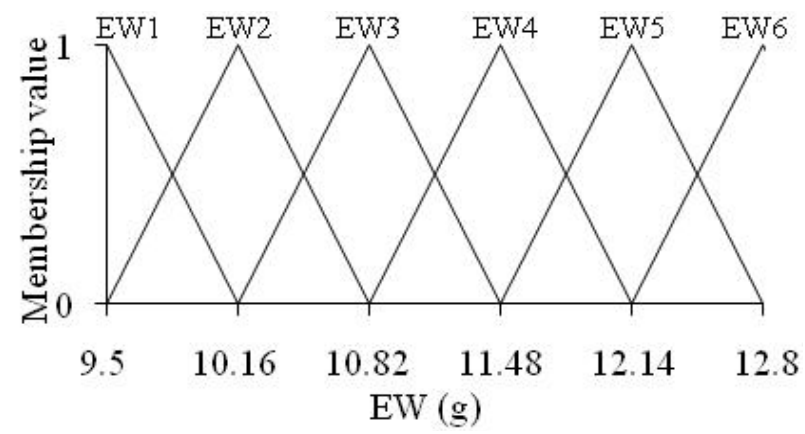

Figure 2 - Membership functions for the output variable egg weight $(\mathrm{EW})$.

The development of the membership functions for the output variables was based on field data collection and on research conducted by Pinto et al. (2003), Araujo et al. (2007), Barreto et al. (2007), Umigi et al. (2007), Moura et al. (2010a), Moura et al. (2010b), and Vercese (2010), Lima et al. (2011); who reported information regarding egg weight under six temperatures and four humidity levels, totaling twenty-four thermal conditions.

The rule base was composed by a collection of fuzzy propositions, presented as if-and-then and was developed from the information in Table 1 with the aid of specialists in the field. The rule system was composed of twenty-four rules, with a weighting factor equal to 1 , which was assigned to each rule, similar to several fuzzy models previously adjusted (OLIVEIRA et al., 2005. FERREIRA et al., 2007).

\section{RESULTS AND DISCUSSION}

The surface illustrated in Figure 3 shows the EW profile in relation to $t_{d b}$ and $\mathrm{RH}$.

The peaks in Figure 3 indicate the $t_{d b}$ and RHranges where egg weight (EW) is higher and conversely the depressions indicate the environmental tracks $\left(\mathrm{t}_{\mathrm{db}}, \mathrm{RH}\right)$ where EW values are lower. The surface of Figure 3 illustrates the damage that can be caused by high temperature on the weight of Japanese quail eggs, as the lowest weights are found where the temperature was above $26^{\circ} \mathrm{C}$.

One of the major physiological effects deriving from elevated temperature is the induction of hyperventilation during breathing for heat dissipation, with excessive loss of blood carbon dioxide, an important factor in the formation of calcium carbonate for the shell (JACOME et al., 2007). The results for high temperature can be directly seen on the shell thickness, which becomes thinner (ALVES et al., 2007) and more prone to breaking and cracking. Simultaneously, a high temperature environment causes a reduction in food consumption, which in turn determines a decrease in consumption of calcium, phosphorus and vitamin D3 (TRINDADE et al., 2007).

In this case, the fuzzy system could be embedded in an environment control system for the production area activating fans, evaporative cooling systems and issuing warning signals, thus avoiding exposure of the animal to the stressful environment and economic losses to the producer.

When creating a new computer system in order to support decisions, assessments and tests become important for a better reliability of the system. Thus, the values for $\mathrm{EW}$, measured experimentally and simulated using the proposed fuzzy model, are listed in Table 3.

The absolute deviation between the values observed and estimated by the fuzzy model for egg weight varied between $0.01 \mathrm{~g}$ and $0.32 \mathrm{~g}$ and the average deviation was $0.14 \mathrm{~g}$ (Table 3). The distribution of absolute deviation (Figure 4) indicates that the fuzzy system realistically estimated the weight of the eggs for the environmental conditions in this work, since the deviations were concentrated below $0.20 \mathrm{~g}(79.49 \%)$, which represents $2 \%$ of the average weight for Japanese quail eggs that is $10 \mathrm{~g}$ as reported by Albino and Barreto (2003). 


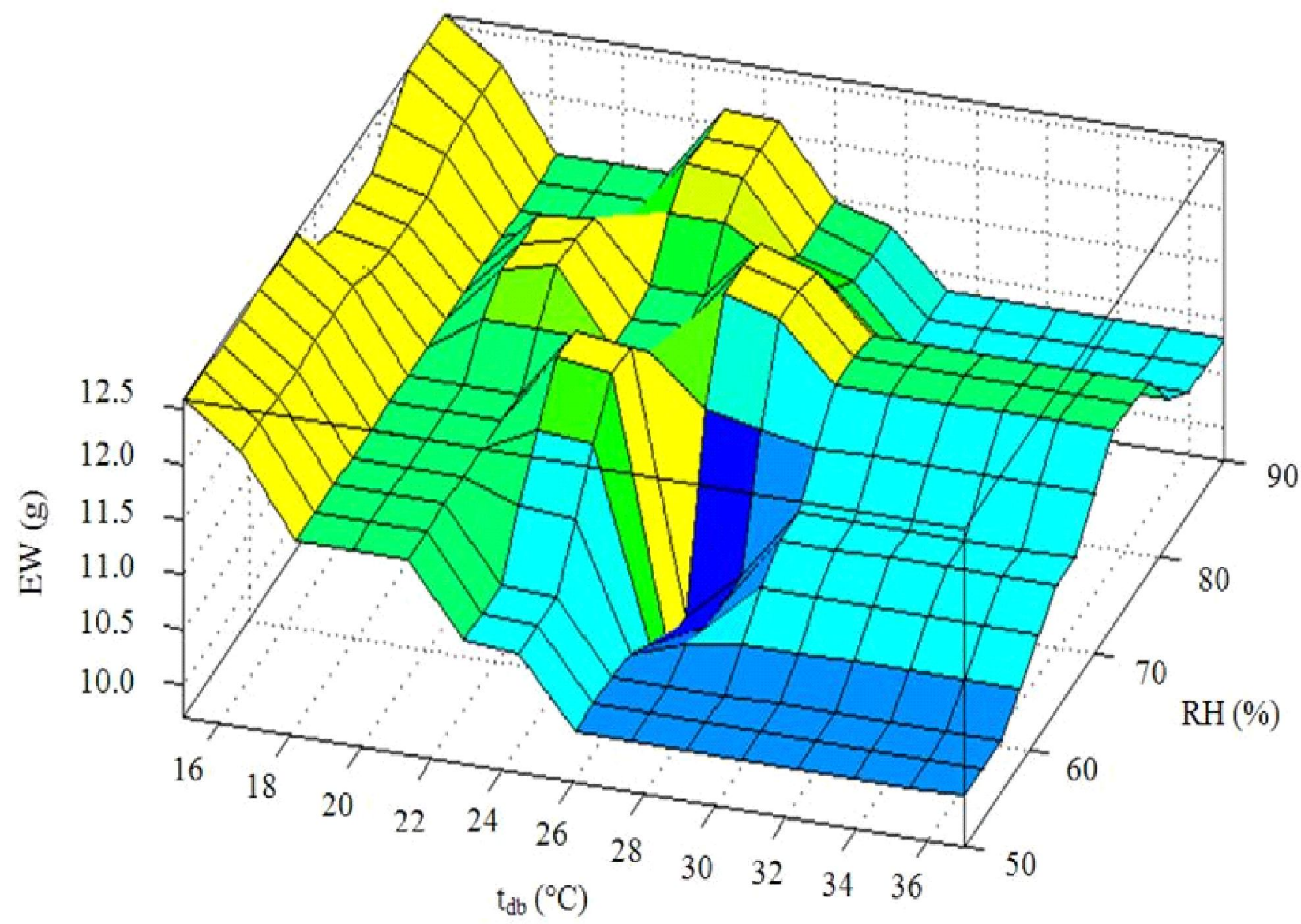

Figure 3 - Egg weight (EW) from laying quails in relation to air dry-bulb temperature $\left(\mathrm{t}_{\mathrm{db}}\right)$ and relative humidity $(\mathrm{RH})$.

The minimum, average and maximum percentage errors found for the fuzzy model were $0.17 \%, 2.33 \%$ and $5.68 \%$, respectively. The average error found was lower than the one found for the other technique used by Silva et al. (2011), recovering the three-dimensional shape of eggs, which found errors ranging from $2.60 \%$ to $5.47 \%$.

The functional relationship between the EW observed and simulated is illustrated in Figure 5, and the determination coefficient $\left(R^{2}\right)$ was 0.688 . It should be noted that $\mathrm{R}^{2}$ is not the only nor the best index to evaluate the performance of a model, which can be verified by the low values for average absolute deviation and average percentage error $(0.14 \mathrm{~g}$ and $2.33 \%$. respectively).

Laying birds are exposed to other factors, which are not environmental, in addition to the animal's own inherent factors that can influence size and weight of eggs.

Heavier eggs can be observed in older birds. Trindade et al. (2007) observed, when assessing environmental and productive indices in reference to the age of housed birds, that egg weight increased with age.

Animal improvement allows commercial strains to have different performance. Móri et al. (2005) when assessing the potential for egg production and quality from four genetic groups of quail, observed differences between the egg weight in different groups.

The feed received by the bird may directly affect their performance and thereby egg weight. Pinheiro et al. (2008) when working with different levels of protein in the diet of laying quails, observed that the weight of eggs was influenced by the daily consumption of protein. 
Table 3 - Comparison between egg weight (EW) values observed and simulated by the fuzzy model as a function of air dry-bulb temperature $\left(\mathrm{t}_{\mathrm{db}}\right)$ and relative humidity $(\mathrm{RH})$.

\begin{tabular}{|c|c|c|c|c|c|c|}
\hline & \multirow[b]{2}{*}{$\mathrm{t}_{\mathrm{db}}\left({ }^{\circ} \mathrm{C}\right)$} & \multirow[b]{2}{*}{$\mathrm{RH}(\%)$} & \multicolumn{4}{|c|}{ Egg Weight (g) } \\
\hline & & & Observed $^{*}$ & Fuzzy model & $\begin{array}{l}\text { Absolute } \\
\text { Deviation }\end{array}$ & Error \% \\
\hline 1 & 16.79 & 63.75 & 12.06 & 12.00 & 0.03 & 0.50 \\
\hline 2 & 18.27 & 57.98 & 11.64 & 11.50 & 0.07 & 1.20 \\
\hline 3 & 18.80 & 58.83 & 11.67 & 11.50 & 0.09 & 1.46 \\
\hline 4 & 18.77 & 63.84 & 11.55 & 11.50 & 0.03 & 0.43 \\
\hline 5 & 19.20 & 60.67 & 11.94 & 11.50 & 0.22 & 3.69 \\
\hline 6 & 20.90 & 62.37 & 11.10 & 11.50 & 0.20 & 3.60 \\
\hline 7 & 21.21 & 67.07 & 11.86 & 11.50 & 0.18 & 3.04 \\
\hline 8 & 21.69 & 66.35 & 11.38 & 11.70 & 0.16 & 2.81 \\
\hline 9 & 20.54 & 69.43 & 12.12 & 11.80 & 0.16 & 2.64 \\
\hline 10 & 21.54 & 74.00 & 11.90 & 12.10 & 0.10 & 1.68 \\
\hline 11 & 21.08 & 79.00 & 11.87 & 12.00 & 0.07 & 1.10 \\
\hline 12 & 21.65 & 80.00 & 11.53 & 11.90 & 0.19 & 3.21 \\
\hline 13 & 22.24 & 59.12 & 10.83 & 11.40 & 0.29 & 5.26 \\
\hline 14 & 22.56 & 65.83 & 12.20 & 12.10 & 0.05 & 0.82 \\
\hline 15 & 22.07 & 69.29 & 11.56 & 11.90 & 0.17 & 2.94 \\
\hline 16 & 22.67 & 71.30 & 12.18 & 11.80 & 0.19 & 3.12 \\
\hline 17 & 23.43 & 70.50 & 11.67 & 11.80 & 0.07 & 1.11 \\
\hline 18 & 23.27 & 75.36 & 11.80 & 11.50 & 0.15 & 2.54 \\
\hline 19 & 23.97 & 70.36 & 11.77 & 11.80 & 0.02 & 0.25 \\
\hline 20 & 23.43 & 80.00 & 11.78 & 11.80 & 0.01 & 0.17 \\
\hline 21 & 24.38 & 71.88 & 11.90 & 11.60 & 0.15 & 2.52 \\
\hline 22 & 23.85 & 71.50 & 11.10 & 11.60 & 0.25 & 4.50 \\
\hline 23 & 23.79 & 74.07 & 11.63 & 11.50 & 0.07 & 1.12 \\
\hline 24 & 23.61 & 71.64 & 11.30 & 11.60 & 0.15 & 2.65 \\
\hline 25 & 21.72 & 80.57 & 11.44 & 11.80 & 0.18 & 3.15 \\
\hline 26 & 22.96 & 81.29 & 12.41 & 11.90 & 0.26 & 4.11 \\
\hline 27 & 26.58 & 60.46 & 9.88 & 10.00 & 0.06 & 1.21 \\
\hline 28 & 24.55 & 74.00 & 11.89 & 11.60 & 0.15 & 2.44 \\
\hline 29 & 24.55 & 75.05 & 12.01 & 11.60 & 0.21 & 3.41 \\
\hline 30 & 24.99 & 73.06 & 11.80 & 11.90 & 0.05 & 0.85 \\
\hline 31 & 25.39 & 76.50 & 11.78 & 12.00 & 0.11 & 1.87 \\
\hline 32 & 25.66 & 73.93 & 12.57 & 12.10 & 0.24 & 3.74 \\
\hline 33 & 25.99 & 79.50 & 12.03 & 11.90 & 0.06 & 1.08 \\
\hline 34 & 27.20 & 79.70 & 11.26 & 11.90 & 0.32 & 5.68 \\
\hline 35 & 26.80 & 81.40 & 11.90 & 11.70 & 0.10 & 1.68 \\
\hline 36 & 36.52 & 58.36 & 10.10 & 10.40 & 0.15 & 2.97 \\
\hline 37 & 31.80 & 64.90 & 10.77 & 10.80 & 0.02 & 0.28 \\
\hline 38 & 33.66 & 73.60 & 11.16 & 11.50 & 0.17 & 3.05 \\
\hline \multirow[t]{2}{*}{39} & 30.37 & 74.28 & 11.85 & 11.50 & 0.18 & 2.95 \\
\hline & & & & Average & 0.14 & 2.33 \\
\hline
\end{tabular}

\footnotetext{
${ }^{*}$ The observed values come from field measurements and literature data.
} 


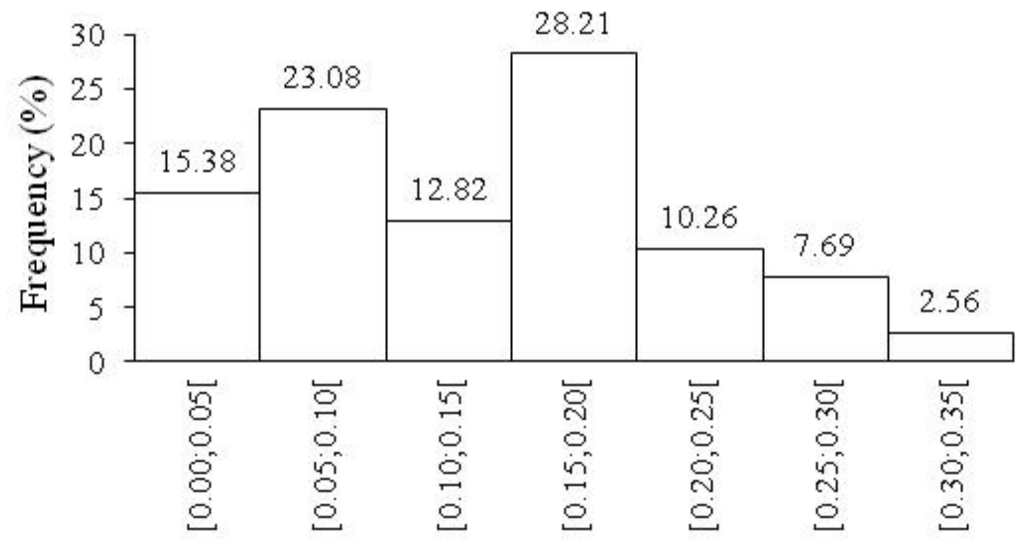

Classes of absolute deviation of egg weight $(\mathrm{g})$

Figure 4 - Frequencies observed for absolute deviation between the weights of Japanese quail eggs estimated by the fuzzy model as a function air dry-bulb temperature $\left(\mathrm{t}_{\mathrm{db}}\right)$ and relative humidity $(\mathrm{RH})$.

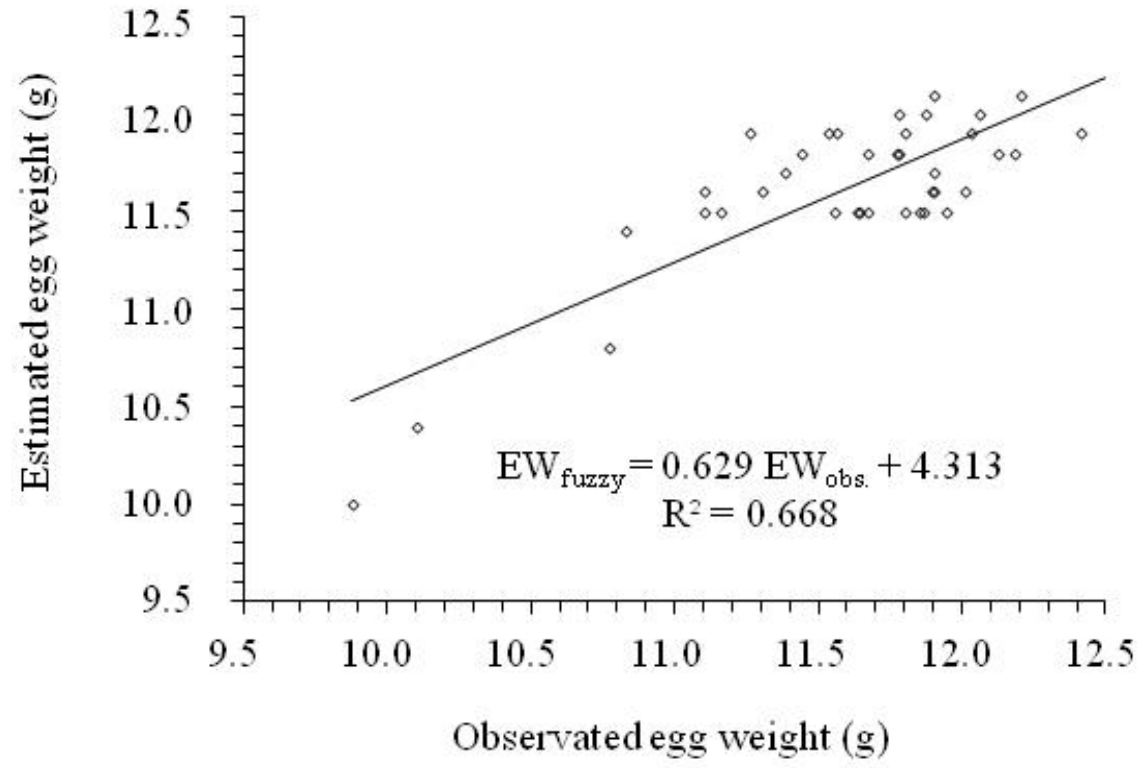

Figure 5 - Determination coefficient $\left(\mathrm{R}^{2}\right)$ generated from the observed egg weight $(\mathrm{EW})$ and estimated egg weight by the fuzzy logic. 


\section{CONCLUSION}

The fuzzy model developed to estimate the weight of Japanese quail eggs, based on the air dry-bulb temperature $\left(\mathrm{t}_{\mathrm{db}}\right)$ and relative humidity $(\mathrm{RH})$, provided low average values for absolute deviation and percentage error $(0.14 \mathrm{~g}$ and $2.33 \%$, respectively), which allowed to realistically estimate the weight of eggs in different environmental conditions.

\section{REFERENCES}

ALBINO, L.F.T.; BARRETO, S.L.T. Criação de codornas para produção de ovos e carne. 1 ed. Viçosa:Aprenda Fácil Editora. 2003. 289p.

ALVES, S.P.; SILVA, I.J.O.P.; STEFANO, S.M. Avaliação do bem-estar de aves poedeiras comerciais: efeitos do sistema de criação e do ambiente bioclimático sobre o desempenho das aves e a qualidade de ovos. Revista Brasileira de Zootecnia, Viçosa, v.36, n.5, p. 1388-1394, set./out., 2007.

AMENDOLA, M. et al. Análise matemática de conforto térmico para avicultura usando a teoria dos conjuntos fuzzy. Biomatemática, n.14, p.87-92, 2004.

AMENDOLA, M.; SOUZA, A.L. Manual do uso da teoria dos conjuntos fuzzy no MATLAB 6.1. Campinas: FEAGRI/UNICAMP, 2004. 30p.

ARAÚJO, M.S. et al. Níveis de cromo orgânico na dieta de codornas japonesas mantidas em estresse por calor na fase de postura. Revista Brasileira de Zootecnia, Viçosa, v.36, n.3, p.584-588, maio/ jun., 2007.

BARRETO, S.L.T. et al. Níveis de sódio em dietas para codorna japonesa em pico de postura. Revista Brasileira de Zootecnia, Viçosa, v.36, n.5, p.1559-1565, set./out., 2007.

BORGES, G. et al. Uso da geoestatística para avaliar a captação automática dos níveis de pressão sonora em instalações de creche para suínos. Engenharia Agrícola, Jaboticabal, v.30, n.3, p.377-385, 2010.

FERREIRA, L. et al. Development of algorithm using fuzzy logic to predict estrus in dairy cows: part I. Agricultural Engineering International: the CIGR Ejournal. Manuscript IT 06 004. Vol.IX. September. 2007.
JÁCOME, I.M.T.D. et al. Avaliação de índices de conforto térmico de instalações para poedeiras no nordeste do Brasil. Revista Brasileira de Engenharia Agrícola e Ambiental, Campina Grande, v.11, n.5, p.527531, sep./oct., 2007.

LIMA. H.J.D. et al. Dietary phytase levels on performance and egg quality of japanese quails. Revista Brasileira de Zootecnia, Viçosa, v.40, n.1, p.129-134, jan., 2011.

MÓRI, C. et al. Desempenho e qualidade dos ovos de codornas de quatro grupos genéticos. Revista Brasileira de Zootecnia, Viçosa, v.34, n.3, p.864-869, maio/jun., 2005.

McDOWELL, R.E. Bases biológicas de la producción animal em zonas tropicales. 1.ed. Zaragoza: Acribia, 1974. 692p.

MOURA, A.M.A. Utilização do sorgo, de pigmentos sintéticos e de selênio orgânico em rações para codornas japonesas (Coturnix japonica) em postura. 2008. 134p. Tese (Doutorado em Produção Animal), Universidade Estadual do Norte Fluminense. 2008.

MOURA, A.M.A. et al. Desempenho e qualidade do ovo de codornas japonesas alimentadas com rações contendo sorgo. Revista Brasileira de Zootecnia, Viçosa, v.39, n.12, p.2697-2702, dez., 2010a.

MOURA, G.S.; BARRETO, S.L.T.; LANNA, E.A.T. Efeito da redução da densidade energética de dietas sobre as características do ovo de codorna japonesa. Revista Brasileira de Zootecnia, Viçosa, v.39, n.6, p.1266-1271, jun., $2010 \mathrm{~b}$.

NASCIMENTO, G.R. et al. Índice fuzzy de conforto térmico para frangos de corte. Engenharia Agrícola, Jaboticabal, v.31, n.2, p.219-229, mar./abr., 2011.

OLIVEIRA, H.L.; AMENDOLA, M.; NÄÄS, I.A. Estimativa das condições de conforto térmico para avicultura de postura usando a teoria dos conjuntos fuzzy. Engenharia Agrícola, Jaboticabal, v.25, n.2, p.300307, maio/ago., 2005.

PANDORFI, H. et al. Uso da lógica fuzzy na caracterização do ambiente produtivo para matrizes gestantes. Engenharia Agrícola, Jaboticabal, v.27, n.1, p.83-92, jan./abr., 2007. 
PERISSINOTTO, M. et al Conforto térmico de bovinos leiteiros confinados em clima subtropical e mediterrâneo pela análise de parâmetros fisiológicos utilizando a teoria dos conjuntos fuzzy. Ciência Rural, Santa Maria, v. 39, n. 5, Agosto, 2009. Disponível em: <http://www.scielo.br/

scielo.php?script=sci_arttext $\&$ pid $=$ S0103-

$84782009000500029 \& \operatorname{lng}=\mathrm{en} \& n \mathrm{rm}=\mathrm{iso}>$. Acessado em: $30 / 07 / 2011$.

PINHEIRO, S.R.F. et al. Efeito dos níveis de triptofano digestível em dietas para codornas japonesas em postura. Revista Brasileira Zootecnia, Viçosa, v.37, n.6, p.1012-1016, jun., 2008.

PINTO, R. et al. Exigência de metionina mais cistina para codornas japonesas em postura. Revista Brasileira Zootecnia, Viçosa, v.32, n.5, p.1166-1173, set./out., 2003.

PONCIANO, P.F. et al. Análise do ambiente para frangos por meio da lógica fuzzy: uma revisão. Archivos de Zootecnia, Córdoba, v.60, n.1, p.1-13, 2011.

ROCHA, H.P. et al. Índices bioclimáticos e produtivos em diferentes galpões avícolas no semiárido paraibano.

Revista Brasileira de Engenharia Agrícola e Ambiental, Campina Grande, v.14, n.12, p.1330-1336, dez., 2010.
SCHIASSI, L. et al. Metodologia fuzzy aplicada à avaliação do aumento da temperatura corporal em frangos de corte. Engenharia na Agricultura, Viçosa, v.16, n.2, p.180-180, 191, abr./jun., 2008.

SILVA, G.C.A. et al. Recuperação da topografia de ovos por meio da técnica de moiré e calibração independente. Engenharia Agrícola, Jaboticabal, v.31, n.2, p.211-218, mar./abr., 2011.

VERCESE, F. Efeito da temperatura sobre o desempenho e qualidade dos ovos de codornas japonesas. 2010. 59p. Dissertação (Mestrado em Zootecnia) - Faculdade de Medicina Veterinária e Zootecnia. Universidade Estadual Paulista.

TRINDADE, J.L.; NASCIMENTO, J.W.B.; FURTADO, D.A. Qualidade do ovo de galinhas poedeiras criadas em galpões no semi-árido paraibano. Revista Brasileira de Engenharia Agrícola e Ambiental, Campina Grande, v.11, n.6, p.652-657, nov./dez., 2007.

UMIGI, R.T. et al. Níveis de treonina digestível em dietas para codorna japonesa em postura. Revista Brasileira Zootecnia, Viçosa, v.36, n.6, p.1868-1874, nov./dez., 2007.

YOUNG, B.A. Effect of environmental stress on nutrient needs. In: CHURCH, D.C. (Ed.) The ruminant animal, New Jersey: Prentice Hall, 1988. p.456-467. 
